7. Reprod. Fert. (1972) 28, 95-97

\title{
THE INFLUENCE OF FOLLICULAR FLUID AND PLASMA ON THE STEROIDOGENIC ACTIVITY OF EQUINE GRANULOSA CELLS
}

\author{
E. V. YOUNGLAI* \\ Department of Veterinary Clinical Studies, University of Cambridge
}

(Received 18th Fune 1971, accepted 24th August 1971)

Different cell types of the ovarian follicle have been used to study steroid biosynthetic pathways. These investigations involved the use of tissue culture (Channing \& Grieves, 1969) and incubations in vitro with specific buffers (Ryan \& Short, 1965; Ryan, Petro \& Kaiser, 1968). The activity of these cells in biological fluids has not been extensively studied. The aim of the present investigation was, therefore, to compare plasma and follicular fluid as incubating media for the biochemical study of the $3 \beta$-hydroxysteroid dehydrogenase and aromatizing activities of granulosa cells from equine ovarian follicles obtained at oestrus.

Radioactive steroids of high specific activity were purchased from the Radiochemical Centre, Amersham, Bucks., and were checked for purity before use. Reproductive tracts were obtained at slaughter from four mares judged to be in oestrus by gross examination of the uterus, cervix and corpus luteum using the criteria outlined by Channing (1969). At the time of slaughter, blood was collected in a heparinized bottle. Follicular fluid from the largest, most vascular follicle was aspirated and centrifuged at $2000 \mathrm{rev} / \mathrm{min}$ for $20 \mathrm{~min}$. The granulosa cells were removed from the follicle (Channing, 1969), weighed and suspended in 10-ml portions of plasma or follicular fluid containing radioactive pregnenolone and androstenedione. When $\left[{ }^{3} \mathrm{H}\right]$ pregnenolone was incubated, $2 \mu \mathrm{Ci}$ amounts were used and when $\left[{ }^{14} \mathrm{C}\right]$ androstenedione was incubated, $1 \mu \mathrm{Ci}$ amounts were used. In some instances, $\left[{ }^{3} \mathrm{H}\right]$ androstenedione and $\left[{ }^{14} \mathrm{C}\right]$ pregnenolone were used but amounts were the same with respect to the isotope. Plasma and follicular fluid came from the same mare as that from which the granulosa cells were obtained.

Incubation was carried out at $37^{\circ} \mathrm{C}$ for $1 \mathrm{hr}$ with agitation of the incubating vessels. Processing of the incubation medium was carried out according to Channing \& Grieves (1969). Following extraction with diethyl ether and fractionation into phenolic and neutral steroids, each fraction was purified by paper chromatography. Radiochemical purity of the progesterone, oestrone and oestradiol-17 $\beta$ was confirmed by crystallization to constant specific activity with carrier steroid and the percentage conversion was computed from the final specific activities and the amount of carrier added. Other metabolites were not further processed.

* Present address: Department of Obstetrics and Gynecology, McMaster University, Henderson General Hospital, Hamilton 53, Ontario, Ganada. 
All the oestrous follicles used in the biochemical studies had a well-defined theca interna with a rich blood supply. Table 1 lists these follicles, their size, the weight of granulosa cells incubated and the percentage conversion of pregnenolone to progesterone and of androstenedione to oestrone and oestradiol-17 $\beta$. These data clearly demonstrate that the equine granulosa cells have an active $3 \beta$-hydroxysteroid dehydrogenase system and a quiescent aromatizing system, and are in agreement with other published data (Short 1964; Channing \& Grieves, 1969; YoungLai \& Short, 1970). Other investigators have found good aromatizing activity with the same type of granulosa cells (Channing, 1969; Mahajan \& Samuels, 1963; Ryan \& Short, 1965). However, these all

TABLE 1

PERCENTAGE GONVERSION OF PREGNENOLONE TO PROGESTERONE AND OF ANDROSTENEDIONE TO OESTRADIOL AND OESTRONE BY EQUINE GRANULOSA CELLS GOLLEGTED AT OESTRUS, AND INCUBATED FOR 1 HR IN FOLLICULAR FLUID AND PLASMA

\begin{tabular}{|c|c|c|c|c|c|}
\hline $\begin{array}{c}\text { Exp. } \\
\text { no. }\end{array}$ & $\begin{array}{c}\text { Diameter } \\
\text { of } \\
\text { follicle } \\
(\mathrm{cm})\end{array}$ & $\begin{array}{l}\text { Wt of } \\
\text { cells } \\
(m g)\end{array}$ & $\begin{array}{l}\text { Pregnenolone } \\
\text { to } \\
\text { progesterone }\end{array}$ & \multicolumn{2}{|c|}{$\begin{array}{c}\text { Androstenedione } \\
\text { to } \\
\text { oestradiol }-17 \beta \text { and oestrone }\end{array}$} \\
\hline Y4 & 1.6 & $\begin{array}{r}F^{x}-17 \\
P-20\end{array}$ & $\begin{array}{l}6 \cdot 49 \\
4 \cdot 47\end{array}$ & $\begin{array}{l}0.45 \\
0.01\end{array}$ & - \\
\hline Y6 & 6.0 & $\begin{array}{l}\text { F-52 } \\
\text { P-66 }\end{array}$ & $\begin{array}{l}38.36 \\
43 \cdot 43\end{array}$ & $\begin{array}{l}2 \cdot 88 \\
2 \cdot 11\end{array}$ & $\begin{array}{l}2 \cdot 79 \\
2 \cdot 55\end{array}$ \\
\hline Y7 & 4.0 & $\begin{array}{l}\text { F-32 } \\
\text { P-40 }\end{array}$ & $\begin{array}{r}13.53 \\
7.89\end{array}$ & $\begin{array}{l}\text { lost } \\
\text { lost }\end{array}$ & - \\
\hline Y9 & $5 \cdot 5$ & $\begin{array}{l}\text { F-34 } \\
\text { P-40 }\end{array}$ & $\begin{array}{l}50 \cdot 91 \\
29 \cdot 76\end{array}$ & $\begin{array}{l}2.22 \\
1.35\end{array}$ & $\stackrel{5 \cdot 96}{-}$ \\
\hline Y9T & & $\begin{array}{l}\text { F-44 } \\
\text { P-52 }\end{array}$ & $\begin{array}{l}9.41 \\
1.71\end{array}$ & $\begin{array}{l}0.01 \\
0.28\end{array}$ & $\stackrel{0.01}{-}$ \\
\hline
\end{tabular}

$F^{x}$ refers to incubations in follicular fluid and $P$ in plasma. Except for Y9T where theca cells were used, all other incubations were carried out with granulosa cells. Experiments Y9 and Y9T were performed on the same Graafian follicle. Theca cells were peeled off from the intact follicle after removal from the ovary.

* Not detected.

involved in vitro techniques, such as tissue culture, which cause the granulosa cells to luteinize and incubations which may not be representative of the situation in vivo. The $3 \beta$-hydroxysteroid dehydrogenase activity in the granulosa cells has also been confirmed histochemically and found to be confined to this layer (M. F. Hay, personal communication). The $17 \beta$-hydroxysteroid dehydrogenase activity was slight, as seen in the formation of oestradiol-17 $\beta$. The differences in enzymatic activities between plasma and follicular fluid as incubating media are of some interest. Plasma and follicular fluid differ in many respects, including the concentrations of steroids (Short, 1964). Furthermore, follicular fluid but not serum can be used to capacitate spermatozoa (Yanagimachi, 1969, 1970), though, after pretreatment with moderate heat, serum can induce capacitation (Yanagimachi, 1970). In one experiment (Y9T), theca cells also were incubated; they converted pregnenolone to progesterone and androstenedione to oestradiol-17 $\beta$ though not to the same extent as the granu- 
losa cells from the same follicle. Though these cells were taken from the outer layer of the follicle, it was not determined whether they were derived from the theca externa, the theca interna or both. In a previous investigation, it was suggested that the lower aromatizing activity of the granulosa cells in vivo may be due to product inhibition (YoungLai \& Short, 1970). In this respect, the present study shows that follicular fluid may be a better incubation medium than plasma which does not contain much steroid. These observations strengthen the suggestion that there are essential differences between homologous plasma and follicular fluid.

This work was done during the tenure of a Fellowship from the Medical Research Council of Canada. Dr R. V. Short kindly provided advice and laboratory facilities.

\section{REFERENCES}

Channing, G. P. (1969) Studies on tissue culture of equine ovarian cell types: pathways of steroidogenesis. 7. Endocr. 43, 403.

Channing, C. P. \& Grieves, S. A. (1969) Studies on tissue culture of equine ovarian cell types: steroidogenesis. F. Endocr. 43, 391.

Mahajan, D. K. \& Samuels, L. T. (1963) Biosynthesis of steroids by different ovarian tissues. Fedn Proc. Fedn Am. Socs exp. Biol. 22, 531.

Ryan, K. J., Perro, F. \& Kaiser, J. (1968) Steroid formation by isolated and recombined ovarian granulosa and thecal cells. F. clin. Endocr. Metab. 28, 355.

RYAN, K. J. \& SHORT, R. V. (1965) Formation of estradiol by granulosa and thecal cells of the equine ovarian follicle. Endocrinology, 76, 108.

Short, R. V. (1964) Ovarian steroid synthesis and secretion in vivo. Recent Prog. Horm. Res. 20, 303.

YANAGIMACHI, R. (1969) In vitro capacitation of hamster spermatozoa by follicular fluid. $\mathcal{F}$. Reprod. Fert. $18,275$.

YANAGIMAGHI, R. (1970) In vitro capacitation of golden hamster spermatozoa by homologous and heterologous blood sera. Biol. Reprod. 3, 147.

Younglat, E. V. \& ShORT, R. V. (1970) Pathways of steroid biosynthesis in the intact Graafian follicle of mares in oestrus. F. Endocr. 47, 321. 